\title{
Knowledge and Use of Standardized Nursing Languages: A Study among Nurses at the Federal Medical Centre, Owo, Ondo State, Nigeria
}

\author{
Article by Abiodun-Sanni Falilat Iyabode \\ Texila America University, Guyana, South America \\ E-mail: iyabode.faith@yahoo.com
}

\begin{abstract}
The Standardized Nursing Languages (SNLs) is a new innovation in nursing which is aimed at improving the standard of nursing practice and the professionalism of Nursing. This study was carried out to know the level of knowledge and utilization of Standardized Nursing languages among nurses at the Federal Medical centre Owo. It was aimed at identifying nurses familiarity with the Language, their level of knowledge, use in patient care and also to identify the possible barriers that might prevent the use of the Language in Practice. The use of SNLs is still not gaining popularity among nurses in this tertiary institution, despite its formal introduction to Nigeria since 2010, hence the need for this research work.

A descriptive/correlational design was employed using a self-structured questionnaire. A sample size of 250 nurses was targeted and sampled using a non-probability technique. The data was entered using the SPSS software and analysis done using tables of frequency and percentage, mean and standard deviation, chi test, Pearson correlation where necessary.

Result showed that nurses have a poor knowledge of SNLs. They are mostly familiar with NANDA. The major method of documentation was paper as they have no computer system in their unit. 54\% of respondents use SNLs at work most of which are not correct based on the responses given. Correlation showed that there is no significant difference between years of experience, qualification of nurses and their knowledge of SNLs. ( $p>0.05)$. The major challenges identified by the respondents include poor knowledge of the language, lack of basic amenities, poor policy, inefficient continuous education, shortage of manpower.

High quality nursing documentation promotes effective communication in the healthcare team, which facilitates continuity and individuality of care. The use of SNLs promotes quality nursing documentation and enhances the visibility of the contribution of nursing to patient care.
\end{abstract}

Keywords: Standardized Nursing Languages, Knowledge, Practice, NANDA-I, NIC, NOC.

\section{Introduction}

The changing mode of delivering health care has brought about the need to provide consumers of care with high quality services i.e. Client/patient centered care that is safe, based on best available evidence with quality indicators and clinical outcomes. Nursing care is highly important in the achievement of the objectives of health care delivery. In nursing practice, documenting the patient record is part of a nurse's daily routine. Documentation is essential for adequate, safe and efficient care (IOM, 2004). Inaccurate nursing documentation can cause misinterpretations, and can lead to unsafe patient care (Koczmara, C., Jelincic, V., Dueck, C. (2005). To identify potential areas for improvement the World Alliance for Patient Safety recommends further research toward medical and nursing documentation. This will enable best practices to be established to develop strategies for improving patient safety (WHO, 2007).

Fajemilehin (2014) observed that has become so difficult to measure the contribution of nurses to the health of their patients In other words, nurse-sensitive outcomes have been so difficult to describe. The reasons have been attributed to the nature of current nursing care. Currently, nurses documentations are usually not structured, presented in narrative forms and full of redundancies. It does not show which of the nurse-sensitive outcomes are obtained in patient situations. 
DOI: $10.21522 /$ TIJNR.2015.03.02.Art004

ISSN: $2520-3126$

Olaogun and Adejumo (2104) defined Standardized Nursing Languages as current standards that include terms which represent a focus of health problems ( diagnoses), interventions and outcomes consistent with the scope of nursing practice. Rutherford(2008) gave a similar definition that SNLs describe Nursing care concepts such as diagnosis, interventions and outcomes using common terms to communicate within and across health care systems, health care providers and other health care professionals.

For four decades now, nurses all over the world have been working on how to develop a standardized language for nursing practice, which can be used to serve this purpose. The evolution and development of standardized nursing language has included a systematic program of research over the past 32 years, resulting in significant advancements in nursing knowledge work. The Center for Nursing Classification at the University of Iowa has contributed to the creation of standardized nursing languages that capture nursing interventions (Nursing Interventions Classification [NIC], Dochterman \& Bulechek, 2004), and nurse-sensitive outcomes (Nursing Outcomes Classification [NOC], Moorhead, Maas, \& Johnson, 2003). When these interventions and outcomes are linked with NANDA diagnoses (NANDA International, 2005), all the standardized nursing language pieces (NANDA, NOC, and NIC or NNN) exist to represent relationships between and among nursing diagnoses, interventions, and outcomes (Johnson et al., 2006).

When these languages are used to structure nursing information systems in hospitals and other healthcare organizations, it will be possible to make nursing care and its associated activities and achievement of nursing-sensitive outcomes evident (Lunney, 2006).

Nurses lack training and education to work with a standardized language in actual patient situations. In situations where Nurses are aware of the standardized nursing languages, they have difficulty in transferring their own reasoning process which is related to the assessment of patient within the standardized nursing languages.

Above all, nursing documentation is majorly handwritten as most nurses don't have regular access to computer based tools which enable them to document their nursing assessments, interventions and outcomes in a structured way.

There is need for nurses to perform at a higher level and therefore communicate this contribution to patient care to their colleagues and other health professionals, else, whatever they have done remains invisible. (Hartley and Warren, 2012).

Fajemilehin (2014) also asserted that SNLs will facilitate communication among nurses and between nurses and other health care providers, provide inclusion of nurses in clinical information systems, provide easy access to evidence based knowledge stored in national and international databases, increase visibility of nursing interventions and improve patient care among other.

Significance: This study will create more awareness about SNLs and emphasize the need to fully incorporate the use of SNLs into nursing practice, provide a foundation for future efforts and studies concerned with inclusion of SNLs into nursing documentation within the clinical settings and also assist nursing management of health institutions to see the need to incorporate the use SNLs into nursing practice. This will go a long way in achieving the goal of transition from the traditional practice to evidence-based practice and also enhance communication between nurses and other healthcare professionals.

Objectives: The study is aimed at assessing the level of knowledge of SNLs among nurses, identify which of the SNLs the nurses are familiar with, ascertain if nurses make use of SNLs, and also identify the perceived barriers to its adoption.

\section{Research questions}

1. What is the level of knowledge of SNLs among nurses?

2. Which of the SNLs are nurses most familiar with?

3. Do nurses make use of SNLs?

4. What are nurses' perceived barriers to the adoption of SNLs? 
5. Is there a relationship between Nurses level of education, year of experience and knowledge of SNLs?

\section{Methods}

Research designs: The design is both descriptive and correlational. The correlational design is used to study the relationship between the situations examined (Burns and Groove, 2005). The descriptive part describes the demographic data, knowledge, adoption and perceived barrier to use.

Study area: The study was conducted at the Federal Medical Centre, Owo. It is an ancient city located in the south-western part of Nigeria. It is a 300-bedded hospital with a staff of about 1200 health professionals out of which nurses constitute about 350. The hospital was changed from a General Hospital to a federal Medical Centre in 1989 after being taken over by the Federal Government. It provides care at all the three levels (Primary, Secondary and Tertiary). It is located very close to Ikare-Owo Express Road. The hospital conducts residency training for doctors and serves an area of practical posting for student nurses.

Sampling method: A non-probability convenience sampling of the Nurses at the Federal Medical Centre, Owo, Nigeria.

Sample size: A total of two hundred and fifty (250) questionnaires were distributed with $98 \%$ response rate.

Inclusion/exclusion criteria: All nurses practicing in the various units in the hospital were considered for the study as they all have contact with patients one way or the other.

Instrument for data collection: A self-structured and administered questionnaire was used. It was divided into 4 parts:

1. The demographic data include gender, age, marital status, years of experience etc.

2. Knowledge variables were measured by assessing the nurses' knowledge of the definition of Standardized Nursing languages familiarity with the SNL, source of knowledge and the type of knowledge.

3. The implementation variables are measured by stating which of the languages the nurses are best familiar with and also stating whether the institution uses the SNL in documentation, education and research.

4. The barrier variables were determined by use of open ended question to know the Nurses' perceived barrier to the use of SNL

Ethical consideration: The study is of low risk to participating subjects and the facility.

Copies of the research proposal was submitted to the ethical review board of Federal Medical Centre, Owo for ethical approval of the study. After approval, the purpose of the study was explained to the study participants. Participation in the study was made voluntary and they were told they could withdraw from the study at any point if they wished without any negative consequence. Participants were assured that the information they had given would be treated with confidentially. Informed consent was sought from study participants and each of them signed the consent forms attached to their questionnaires prior to filling them. Respondents did not write their name for the purpose of confidentiality.

Process of data collection: A letter of permission to carry out study was obtained from the authority via the Research Review Committee. The questionnaires were administered to each nurse met in their various units/wards during the period of data collection. Same was collected back from the nurses after 23 days. Data collection lasted a period of 2 weeks in all.

Data analysis: The data was entered using the SPSS software version 22 and analysis done using tables of frequency and percentage, mean and standard deviation, chi test, Pearson correlation where necessary. 
DOI: $10.21522 /$ TIJNR.2015.03.02.Art004

ISSN: $2520-3126$

\section{Results}

\section{Demographic distribution}

The demographic distribution of the respondents revealed that majority (97.1\%) of the respondents was female and $2.9 \%$ are male. The age distribution showed that $8.2 \%$ of respondents were aged between 21 30 , majority (61.2\%) were aged between $31-40,26.5 \%$ were aged between $41-50$ and just few, $4.1 \%$. It is also revealed that majority of the respondents $78.4 \%$, are Christians while $21.6 \%$ are Muslims. None of the respondents is a traditionalist. Most of the respondents $(81.6 \%)$ are Yoruba, just few $(0.4 \%)$ are Hausa while $18 \%$ are Ibo. It is revealed in the statistics that majority of respondents (78.8\%) are married, $15.9 \%$ are single, $0.8 \%$ widowed $4.5 \%$ are separated. Distribution of the year of experience showed that $6.1 \%$ have only worked for less than 5 years, $32.7 \%$ have worked for 5-10 years, the larger numbers of respondents $(36.7 \%)$ have worked for up to 15 years, and $16.3 \%$ have worked for up to 20 years while $8.2 \%$ have worked for more than 20 years. Only $2 \%$ of the respondents have a master's degree, $55 \%$ have a degree while $43 \%$ have only the RN RM qualification. $14.7 \%$ of respondents were Nursing Officer II, 9\% Nursing Officer I, 33.1\% Senior Nursing Officer, 15.9\% were Principal Nursing Officer, 12.2\% are Assistant Chief Nursing Officers, 14.3 are Chief Nursing Officers, 0.8\% are Assistant chief Nursing Officers.

\section{Knowledge}

Responses showed that all the nurses are familiar with standardized Nursing languages. Only $37.6 \%$ of respondents were able to give a correct definition of Standardized Nursing Languages while $62.4 \%$ gave a wrong definition. Only 30\% recognized NANDA, NIC AND NOC as Standardized Nursing Languages. $21 \%$ chose Evaluation, $18 \%$ chose diagnosis while $31 \%$ chose nursing process. Only $12.2 \%$ of respondents were able to recognize that 12 standardized Nursing languages exists. $14.3 \%$ responded 5, $4.1 \%$ recognized $7,2.45 \%$ recognized $10,13.9 \%$ recognized $11,10.2$ responded $13,6.1 \%$ recognized 15 while the majority of respondents $(36.1 \%)$ does not know the number of standardized languages that currently exists. 39\% of respondents got to know about Standardized Nursing Languages at the college, $15 \%$ in the ward, $69 \%$ knew about it from Journals and textbooks while $14 \%$ of respondents could not actually recognize how they got to know about it. When asked which of the languages nurses are most familiar with, majority $42 \%$ are most familiar with NANDA, $4.8 \%$ with aseptic technique, $6.5 \%$ familiar with Nursing Intervention classification, 2.4\% familiar with Nursing Outcome Classification, $8.9 \%$ are familiar with Nursing care plan, $11.4 \%$ mentioned Nursing diagnosis, $4.9 \%$ mentioned Nursing Process

\section{Nurses' use of SNLs}

Responses showed that $100 \%$ of the respondents use paper method of documentation in the care of patients. $100 \%$ also confirmed that they do not have a functioning computer system in their ward. With paper documentation, 54\% of respondents use standardized Nursing languages at work most of which are not correct based on the responses given above, $45.3 \%$ do not use at all. Only $34.3 \%$ make use of Standardized Nursing Languages in their area specialization, $65.7 \%$ does not make use of it. $86 \%$ of the respondents confirmed that the hospital does not train nurses on the use of standardized Nursing Languages. $14 \%$ had no idea. $91 \%$ also confirmed that the hospital does not conduct any research on Standardized Nursing Languages. $9 \%$ had no idea.

\section{Identification of barriers}

The challenges identified by the respondents are poor knowledge of the language (90\%), lack of basic amenities (89\%), inadequate computer literacy (48\%), nurses attitude to change (62\%), lack of policy and standard (77\%), poor leadership (81\%), inefficient continuous education (86\%), lack of management support (72\%), shortage of manpower (88\%), lack of time $(73 \%)$ 


\section{Discussion of finding}

\section{Nurses knowledge of standardized nursing languages}

Statistics showed that a larger percentage of the nurses are familiar with Standardized Nursing Languages, but has a poor knowledge of standardized nursing languages as only $37.6 \%$ of respondents were able to give a correct definition of Standardized Nursing Languages while $62.4 \%$ gave a wrong definition. Only $30 \%$ recognized NANDA, NIC AND NOC as Standardized Nursing Languages. Personal interactions with the nurses showed that some of them only read about it in books and journals, only few learnt about it in the school. They were able to give correct definitions some of which were not given off hand but copied. This is in line with study done by Muller Stuab et al (2006) to assess nursing diagnoses, interventions and outcomes implementation. They reported a deficiency in accurately stating and documenting Nursing diagnosis and to relate them with nursing interventions and outcomes. (Table 4.1).

This is also similar to findings by Ehrenberg and Ehnfors (2001) in one of their studies in which they compared patient records against nurses' reports and found that between $41 \%$ and $89 \%$ of the patient problems identified by nurses 230 were not registered Standardized languages.

A different result was seen in a study conducted by Gusen et al (2016) which revealed that majority (70.9\%) had knowledge of NANDA, NIC and NIC.

It was revealed that most of the respondents are familiar with NANDA. This is similar to research by Olaogun et al, 2011 in their study conducted among nurses at the Obafemi Awolowo University Teaching hospital where it was revealed that Nurses are mostly familiar with NANDA. Also, in a survey by Thede and Schwirian 2011 to assess nurses' experience and attitude at the Ohio State University, in which about 1268 nurses were sampled. Only 4 out of the 12 were familiar. The most recognizable Nurses familiarity with standardized nursing languages being NANDA which over 1/3 revealed that they have used in the school.

In a study by Donald Kautz et al (2006) to analyze the degree to which standardized nursing language was used by baccalaureate nursing students completing Outcome-Present State-Test (OPT) model worksheets in a clinical practicum. A scoring instrument was developed and 100 worksheets were retrospectively analyzed. NANDA nursing diagnoses were correctly stated in $92 \%$ of the OPT models. Nursing Outcomes Classification (NOC) outcomes were explicitly stated in 22\%, and implied in $72 \%$. Interventions matched appropriate Nursing Interventions Classification (NIC) activities in 61\%. NANDA, NIC, and NOC (NNN) language was used inconsistently by students in this sample.

\section{Method of documenting nursing care in the hospital?}

The major method of documenting nursing care in the hospital is the paper method. It was also revealed that none of the wards in the hospital has a functioning computer system. This is consistent with a case study by Matthew K et al (2014) to assess Nurses attitude towards computerization and also use of computer at work. Study was conducted at two hospitals (private and public) in Nairobi Kenya. It was revealed that only one (6.6\%) of the nurses have access to computer system at work in the government hospital. Computers perform a wide range of activities which help nurses to save time with documentation hence improving efficiency of health care. Various studies conducted on standardized Nursing Languages have shown that the use can be made easier with the use of the Electronic Health Record system.

\section{Nurses' perceived barriers to successful adoption of the standardized nursing languages?}

Major barriers identified in the study are include poor knowledge of the language, lack of basic amenities, poor policy, inefficient continuous education, shortage of manpower. This study is in line with the study conducted by Sani and Sani 2017 which revealed that the barriers to utilization of SNL include inadequate knowledge, lack of hospital policy and nurses shortage. Similarly, study by Thede and Schiwirian (2010) which revealed lack of knowledge of standardized nursing Languages as major barrier to its successful utilization. 
DOI: $10.21522 /$ TIJNR.2015.03.02.Art004

ISSN: $2520-3126$

In a study by P Flege in 2009, it was shown that even though classifications have been developed, most nurses have not been trained to use Standardized Nursing Languages. (It is reflected in this study that the hospital does not train nurses on the use of Standardized Nursing Languages).

At the Jos University Teaching Hospital, study by Abraham et al (2015) to determine the knowledge and utilization of SNL among nurses showed inadequate knowledge, lack of man power and lack of equipment as the major barrier.

\section{Relationship between the nurse's year of experience, educational qualification and their knowledge of SNLs}

According to Table 4.5 correlation revealed that there is no significant relationship between the nurses year of experience and their knowledge of Standardized Nursing Languages. (P value>0.05). This is in contrast to a study by Sani and Sani (2015) conducted in Sokoto which revealed that there is a significant difference between the knowledge of standardized nursing language and years of working experience among nurses in Sokoto, $(\mathrm{p}<0.02)$. Furthermore, post hoc analysis revealed that nurses with less than 5years working experience $(\mathrm{M}=6.32, \mathrm{SD}=1.68)$ and those with 5-10 years of working experience $(\mathrm{M}$ $=4.15, \mathrm{SD}=2.03$ ) had more knowledge of SNL, than those with more than 10years of working experience.

Table 4.6 also revealed that there is no significant relationship between the nurses year of experience and their knowledge of standardized nursing languages

\section{Conclusion and recommendation}

The evolution of standardized nursing languages (SNLs) has been occurring for more than four decades. The importance of this work continues to be acknowledged as an effective strategy to delineate professional nursing practice. In today's health care environment, the demand to deliver cost-effective, safe, quality patient care is an essential mandate embedded in all health reform policies. Communicating the contributions of professional nursing practice to other nurses, health providers, and other members of the health care team requires the articulation of nursing's focus of concern and responses to these concerns to improve patient outcomes.

The visibility of the electronic health record (EHR) in practice settings has accelerated the need for nursing to communicate its practice within the structure of the electronic format. The integration of SNLs into the patient record offers nurses an opportunity to describe the focus of their practice through the identification of nursing diagnosis, interventions and outcomes .Continued development, testing, and refinement of SNLs offers nursing an accurate and reliable way to use data elements across populations and settings to communicate nursing practice, enable nursing administrators and leaders in health care to delineate needed resources, cost out nursing care with greater precision, and design new models of care that reflect nurse-patient ratios and patient acuity that are data driven.

The continued use of nursing languages and acceleration of nursing research using this data can provide the needed evidence to help link nursing knowledge to evidence-driven, cost-effective, quality outcomes that more accurately reflect nursing's impact on patient care as well as the health care system of which they are a part. The evaluation of research to support the development, use, and continued refinement of nursing language is critical to research and the transformation of patient care by nurses on a global level. 


\section{List of tables}

Table 4.1. Socio-demographic distribution

\begin{tabular}{|c|c|c|}
\hline Variable & Frequency & Percentage \\
\hline $\begin{array}{l}\text { SEX } \\
\text { Male } \\
\text { Female }\end{array}$ & $\begin{array}{l}7 \\
238\end{array}$ & $\begin{array}{l}2.9 \\
97.1\end{array}$ \\
\hline $\begin{array}{l}\text { AGE } \\
\mathbf{2 1 - 3 0} \\
31-40 \\
41-50 \\
51-60\end{array}$ & $\begin{array}{l}20 \\
150 \\
65 \\
10\end{array}$ & $\begin{array}{l}8.2 \\
61.2 \\
26.5 \\
4.1\end{array}$ \\
\hline $\begin{array}{l}\text { Religion } \\
\text { Christian } \\
\text { Islam } \\
\text { Traditional }\end{array}$ & $\begin{array}{l}192 \\
53\end{array}$ & $\begin{array}{l}78.4 \\
21.6\end{array}$ \\
\hline $\begin{array}{l}\text { Tribe } \\
\text { Yoruba } \\
\text { Hausa } \\
\text { Ibo }\end{array}$ & $\begin{array}{l}200 \\
1 \\
44 \\
\end{array}$ & $\begin{array}{l}81.6 \\
0.4 \\
18 \\
\end{array}$ \\
\hline $\begin{array}{l}\text { Marital Status } \\
\text { Single } \\
\text { Married } \\
\text { Widowed } \\
\text { Separated }\end{array}$ & $\begin{array}{l}39 \\
193 \\
2 \\
11\end{array}$ & $\begin{array}{l}15.9 \\
78.8 \\
0.8 \\
4.5\end{array}$ \\
\hline $\begin{array}{l}\text { Years of } \\
\text { Experience } \\
\text { Under } 5 \\
5-10 \\
11-15 \\
16-20 \\
20 \text { and above } \\
\end{array}$ & $\begin{array}{l}15 \\
80 \\
90 \\
40 \\
20 \\
\end{array}$ & $\begin{array}{l}6.1 \\
32.7 \\
36.7 \\
16.3 \\
\end{array}$ \\
\hline $\begin{array}{l}\text { Qualification } \\
\text { Masters } \\
\text { BNSc } \\
\text { RN/RM } \\
\end{array}$ & $\begin{array}{l}5 \\
135 \\
105 \\
\end{array}$ & $\begin{array}{l}2.0 \\
55 \\
43 \\
\end{array}$ \\
\hline $\begin{array}{l}\text { Designation } \\
\text { NO II } \\
\text { NOI } \\
\text { SNO } \\
\text { PNO } \\
\text { ACNO } \\
\text { CNO } \\
\text { ADNS }\end{array}$ & $\begin{array}{l}36 \\
22 \\
81 \\
39 \\
30 \\
35 \\
2 \\
\end{array}$ & $\begin{array}{l}14.7 \\
9 \\
33.1 \\
15.9 \\
12.2 \\
14.3 \\
0.8\end{array}$ \\
\hline
\end{tabular}

Table 4.2. Knowledge of standardized nursing languages

Variable Frequency Percentage 
DOI: $10.21522 /$ TIJNR.2015.03.02.Art004

ISSN: $2520-3126$

\begin{tabular}{|c|c|c|}
\hline $\begin{array}{l}\text { 1. Are you familiar with standardized } \\
\text { nursing languages? } \\
\text { Yes } \\
\text { No }\end{array}$ & $\begin{array}{l}245 \\
0\end{array}$ & $\begin{array}{l}100 \\
0\end{array}$ \\
\hline $\begin{array}{l}\text { 2. If yes, define standardized nursing } \\
\text { languages }\end{array}$ & & \\
\hline $\begin{array}{l}\text { Correct definition } \\
\quad \text { Wrong definition }\end{array}$ & $\begin{array}{l}92 \\
153\end{array}$ & $\begin{array}{l}37.6 \\
62.4\end{array}$ \\
\hline $\begin{array}{l}\text { 3. Which of the following is a } \\
\quad \text { Standardized Nursing Language? } \\
\text { Evaluation } \\
\text { Diagnosis } \\
\text { NANDA, NIC and NOC } \\
\text { Nursing process }\end{array}$ & $\begin{array}{l}51 \\
44 \\
73 \\
77\end{array}$ & $\begin{array}{l}21 \\
18 \\
30 \\
31\end{array}$ \\
\hline $\begin{array}{l}\text { 4. How many standardized nursing } \\
5 \\
7 \\
10 \\
11 \\
12 \\
13 \\
15 \\
\text { I donguages exist? } \\
\\
15 \text { dnow }\end{array}$ & $\begin{array}{l}35 \\
10 \\
6 \\
34 \\
30 \\
25 \\
15 \\
90\end{array}$ & $\begin{array}{l}14.3 \\
4.1 \\
2.45 \\
13.9 \\
12.2 \\
10.2 \\
6.1 \\
36.7\end{array}$ \\
\hline $\begin{array}{l}\text { 5. Which of the standardized languages are } \\
\quad \text { you most familiar with? } \\
\text { Aseptic technique } \\
\text { NANDA } \\
\text { NIC } \\
\text { NOC } \\
\text { Nursing care plan } \\
\text { Nursing Diagnosis } \\
\text { Nursing Process } \\
\text { No response }\end{array}$ & $\begin{array}{l}12 \\
103 \\
16 \\
6 \\
22 \\
28 \\
12 \\
56\end{array}$ & $\begin{array}{l}4.8 \\
42 \% \\
6.5 \\
2.4 \\
8.9 \\
11.4 \\
4.9 \\
22.85\end{array}$ \\
\hline $\begin{array}{l}\text { 6. What is your source of knowledge? } \\
\text { College } \\
\text { Ward level } \\
\text { Journal/Textbook }\end{array}$ & $\begin{array}{l}96 \\
44 \\
170\end{array}$ & $\begin{array}{l}39 \\
15 \\
69\end{array}$ \\
\hline
\end{tabular}

Table 4.3. Use of standardized nursing languages among nurses at federal medical centre, owo

\begin{tabular}{|l|l|l|}
\hline Variable & Frequency & Percentage \\
\hline $\begin{array}{l}\text { Which method of documentation do you use in } \\
\text { patient care? }\end{array}$ & & \\
$\begin{array}{l}\text { Paper } \\
\text { Electronic health record }\end{array}$ & 245 & 100 \\
\hline $\begin{array}{l}\text { Do you have a functioning computer system in your } \\
\text { ward? }\end{array}$ & - & - \\
\hline Yes & - & \\
\hline No & 245 & - \\
\hline
\end{tabular}


Texila International Journal of Nursing Volume 3, Issue 2, Dec 2017

\begin{tabular}{|l|l|l|}
$\begin{array}{l}\text { Do you make use of standardized nursing languages } \\
\text { at work In planning and documenting care? }\end{array}$ & & \\
\hline Yes & 134 & 54.7 \\
\hline No & 111 & 45.3 \\
\hline $\begin{array}{l}\text { Do you make use of Standardized Nursing } \\
\text { Languages in Your area of specialization? }\end{array}$ & & \\
\hline Yes & 84 & $34.3 \%$ \\
\hline No & 161 & $65.7 \%$ \\
\hline $\begin{array}{l}\text { Does your hospital train nurses on the use of } \\
\text { Standardized Nursing Languages? }\end{array}$ & & \\
\hline Yes & - & $86 \%$ \\
\hline No & 210 & $14 \%$ \\
\hline I have no idea & 35 & \\
\hline $\begin{array}{l}\text { Does your facility conduct research on Standardized } \\
\text { Nursing Languages? }\end{array}$ & & \\
\hline Yes & - & $91 \%$ \\
\hline No & 223 & $9 \%$ \\
\hline I have no idea & 22 & \\
\hline
\end{tabular}

Table 4.4. Possible barriers facing the use of standardized nursing languages at fmc, owo

\begin{tabular}{|l|l|l|}
\hline Variables & Frequency & Percentage \\
\hline $\begin{array}{l}\text { Nurses poor knowledge and of Standardized Nursing } \\
\text { Languages }\end{array}$ & 221 & 90 \\
\hline $\begin{array}{l}\text { Non availability of basic amenities e.g. computer } \\
\text { system, }\end{array}$ & 219 & 89 \\
\hline Continuous power supply, internet facilities etc. & 119 & 48 \\
\hline Inadequate Computer Literacy & 152 & 62 \\
\hline Nurses attitude to change & 188 & 77 \\
\hline Lack of policy/standard & 199 & 81 \\
\hline Poor Leadership & 210 & 86 \\
\hline Inefficient continuous education & 178 & 72 \\
\hline Lack of support from Management & 216 & 88 \\
\hline Staff Shortage & 178 & 73 \\
\hline Lack of time & & \\
\hline & & \\
\hline
\end{tabular}

Table 4.5. Relationship between nurse's year of experience and their knowledge of standardized nursing language

\begin{tabular}{|c|c|c|c|c|c|c|}
\hline & & \multicolumn{2}{|c|}{ Knowledge of SNL* } & \multirow[t]{2}{*}{ Total } & \multirow[b]{2}{*}{$\mathrm{X}^{2}$} & \multirow[b]{2}{*}{ P-value } \\
\hline & & Poor & Fair & & & \\
\hline \multirow[t]{2}{*}{ Under 5 years } & Count & 10 & 5 & 15 & 5.246 & 0.117 \\
\hline & $\%$ of Total & $4.1 \%$ & $2.0 \%$ & $6.1 \%$ & & \\
\hline \multirow[t]{2}{*}{ 5-10 years } & Count & 25 & 55 & 80 & & \\
\hline & $\%$ of Total & $10.2 \%$ & $22.4 \%$ & $32.7 \%$ & & \\
\hline $11-15$ years & Count & 50 & 40 & 90 & & \\
\hline
\end{tabular}


DOI: $10.21522 /$ TIJNR.2015.03.02.Art004

ISSN: $2520-3126$

\begin{tabular}{|l|l|l|l|l|l|l|}
\hline & $\%$ of Total & $20.4 \%$ & $16.3 \%$ & $36.7 \%$ & & \\
\hline \multirow{2}{*}{$16-20$ years } & Count & 10 & 30 & 40 & & \\
\cline { 2 - 8 } & $\%$ of Total & $4.1 \%$ & $12.2 \%$ & $16.3 \%$ & & \\
\hline \multirow{2}{*}{20 and above } & Count & 10 & 10 & 15 & & \\
\cline { 2 - 8 } & $\%$ of Total & $4.1 \%$ & $2.0 \%$ & $6.1 \%$ & & \\
\hline \multirow{2}{*}{ No response } & Count & 0 & 5 & 5 & & \\
\cline { 2 - 8 } & $\%$ of Total & $.0 \%$ & $2.0 \%$ & $2.0 \%$ & & \\
\hline \multirow{2}{*}{ Total } & Count & 105 & 140 & 145 & & \\
\cline { 2 - 8 } & $\%$ of Total & $42.9 \%$ & $57.1 \%$ & $100.0 \%$ & & \\
\hline
\end{tabular}

- Knowledge level was determined using questions 1-4 (Table 4.2). Poor (0-1), fair (2-3), good (4)

Table 4.6. Relationship between Nurses Qualification and Knowledge of Standardized Nursing Languages

\begin{tabular}{|c|c|c|c|c|c|c|}
\hline & \multicolumn{2}{|c|}{ Knowledge of SNL* } & \multirow[t]{2}{*}{ Total } & \multirow[b]{2}{*}{$\mathrm{X}^{2}$} & \multirow[b]{2}{*}{ P-value } \\
\hline & & Poor & Fair & & & \\
\hline \multirow[t]{2}{*}{ RNRM } & Count & 44 & 51 & 95 & 1.442 & 0.114 \\
\hline & $\%$ of Total & $18 \%$ & $20.8 \%$ & $38.8 \%$ & & \\
\hline \multirow[t]{2}{*}{$\mathrm{BNSc}$} & Count & 53 & 72 & 125 & & \\
\hline & $\%$ of Total & $22 \%$ & $29 \%$ & $51.0 \%$ & & \\
\hline \multirow[t]{2}{*}{$\mathrm{MSc}$} & Count & 0 & 5 & 5 & & \\
\hline & $\%$ of Total & $.0 \%$ & $10.0 \%$ & $10.0 \%$ & & \\
\hline \multirow[t]{2}{*}{ No response } & Count & 4 & 16 & 20 & & \\
\hline & $\%$ of Total & $10.0 \%$ & $31 \%$ & $41 \%$ & & \\
\hline \multirow[t]{2}{*}{ Total } & Total & 21 & 28 & 245 & & \\
\hline & $\%$ of Total & $42.9 \%$ & $57.1 \%$ & $100.0 \%$ & & \\
\hline
\end{tabular}

\section{References}

[1].Abraham Ajayi, Richard Adeola, Okpe Daniel, Nanbu Stephen, Nanle Gusen, Ajayi A, Adeola (2015): Knowledge And Utilization Of Standardized Nursing Language Among Nurses In Jos University Teaching Hospital Plateau State, Nigeria. International Professional Nursing Journal and Research. 2015 Sep 18 [Last Modified: 2015 Nov 18]. Edition 1. Doi: 10.001/26ae0c1f377469682e0e989cdae2e6dc.

[2].Erdemir F, Altun E. (2003): Nursing students' self-assessments and opinions about using nursing diagnosis in clinical practice. International Journal of Nursing Terminology Classification.

[3].Everett M. Rogers (2003): Diffusion of Innovations, Fifth Edition, Free Press, New York, p221.

[4].Hebda, Toni lee; czar, Patricia (2013): handbook of informatics for nurses \& healthcare professionals, 5th edition, ( $)$ 2013. Reprinted by permission of Pearson education, inc., upper saddle river, nj.

[5].John, M. E. (2010): Innovations in nursing education and practice (Standardized nursing languages. A paper presented during 2-day scientific conference on innovation and change. Organized by FAME, West African College of Nursing on $18^{\text {th }}-20^{\text {th }}$ May, 2010, at College of Health Technology, Calabar, Cross River State.

[6].Johnson, M., Bulechek, G., Butcher, H., Dochterman, J. M., Maas, M., Moorhead, S., \& Swanson, E. (2006): NANDA, NOC and NIC Linkages. ( $2^{\text {nd }}$ ed.), St. Louis, Missouri: Mosby, Inc.

[7].Jones, D., Lunney, M., Keenan, G., \& Moorehead, S. (2010). Standardized nursing languages: Essential for the nursing work force. Annual Review of Nursing Research, 28(1), 253-294.

[8].Kaminski, J. (Spring 2011).Diffusion of Innovation Theory Canadian Journal of Nursing Informatics, 6(2). Theory in Nursing Informatics Column. http://cjni.net/journal/?p=1444.

[9].Keenan, G. (1999): Use of standardized nursing language will make nursing visible. Michigan Nurse, 72(2), 1213.

[10]. Kennedy, R. (2003). The nursing shortage and the role of technology. Nursing Outlook, 51(3), S33-34. 
[11]. Klehr J, Hafner J, Spelz L M, Steen S., Weaver K(2009): Implementation of Standardized Nomenclature in the electronic Medical Record. International Journal of Nursing Classification. 2990 Oct-Dec 20(4) 160-80. Doi. 10.1111/j.1744-618.2009.01.132.x.

[12]. Korst LM, Eusebio-Angeja AC, Chamorro T, et al. (2003): Nursing documentation time during implementation of an electronic medical record. J Nurs Adm 2003; 33(1):24-30.

[13]. Language for clinical reasoning with the Outcome-Present State-Test (OPT) Model. International Journal of Nursing Terminologies and Classifications, 17, 129-138. DOI: 10.1111/j.1744-618X.2006.00033.x.

[14]. Lee, E., Park, H., Nam, M., \& Whyte, J. (2011). Identification and comparison of interventions performed by Korean school nurses and U.S. school nurses using the nursing interventions classification (NIC). Journal of School Nursing, 27 (2), 93-101. doi: 10.1177/1059840510391095.

[15]. Moss J, Damrongsak M, Gallichio K. (2005): Representing critical care data using the clinical care classification. AMIA Annual Symposium Proceedings. 2005:545-549.

[16]. Müller-Staub, M., Needham, I., Odenbreit, M., Lavin, M.A., \&van Achterberg, T. (2007). Improved quality of nursing documentation: Results of a nursing diagnoses, interventions and outcome implementation study. International Journal of Nursing Terminologies and Classifications, 18, 5-17.

[17]. NANDA International. (2012). nursing diagnosis: Definitions and classification, 2012-2014. Oxford: WhileyBlackwell.

[18]. National Institute of Medicine (IOM), Robert Wood Johnson Foundation. (2010). the future of nursing: Leading change, advancing health. Washington, D.C.: The National Academies Press.

[19]. Olaogun, A., Oginni, M., Oyedeji, T. A., Nnahiwe, B., and Olatubi, I., ( 2011) Assessing the Use of the NANDA- International Nursing Diagnoses at the Obafemi Awolowo University Teaching Hospital Ile Ife, Nigeria. International Journal of Nursing Terminologies and Classifications. Vol 22(4). Oct- Dec pp 157-161.

[20]. Pearson, A. (2003). The role of documentation in making nursing work visible. International Journal of Nursing Practice, 9(5), 271.

[21]. Poissant L, Pereira J, Tamblyn R, et al. The impact of electronic health records on time efficiency of physicians and nurses: a systematic review. J Am Med Inform Assoc 2005; 12:505.

[22]. Rogers, E. M. (2003). Diffusion of innovations (5th ed). New York: Free Press.

[23]. Rutherford, M. A. (2008). Standardized nursing language: What does it mean for nursing practice? The Online Journal of Issues in Nursing, 13. doi: 10.3912/OJIN.Vol13No01PPT05.

[24]. Rutherford, M. A. (2008). Standardized nursing language: What does it mean for nursing practice? Online Journal of Issues in Nursing, OJIN: 13 (1) retrieved 23/11/2011 from http://www.nursingworld.org.

[25]. Sani S, Sani AM. (2015): Relationship between knowledge of standardized nursing language and working experience among nurses in Sokoto, Nigeria. International Journal of Science Resources 2015 .4(2):1008-10.

[26]. Sani S, Sani AM. (2015): Nurses attitude and barriers towards utilization of Standardized Nursing Languages in Sokoto State Nigeria. Asian Journal of Medicine and health, 2(2): 1-6, 2017; Article no. AJMAH.29433.

[27]. Schwirian, P., Thede, L., (May 21, 2012) "Informatics: The Standardized Nursing Terminologies: A National Survey of Nurses' Experience and Attitudes-SURVEY II Participants, Familiarity and Information Sources" OJIN: The Online Journal of Issues in Nursing Vol. 17 No. 2.2.

[28]. Smith K, Smith V, Krugman M, et al. evaluating the impact of computerized clinical documentation. Comput Inform Nurs 2005; 23 (3):132-8.

[29]. World Health Organization (2007). Communication during Patient Hand-Over, Patient Safety Solutions, 1 (3) Solution.pdf accessed: 01 June 2010. 